\title{
O uso sustentável da Água: a PROdução mais limpa EM UMa indústria têxtil do Estado DE São Paulo
}

\author{
Viviane Xavier Ferreira*; Janaína Florinda Ferri Cintrão**; Ethel Cristina Chiari Silva**; Sandra Imaculada \\ Maintinguer** \\ ${ }^{*}$ Mestre em Desenvolvimento Territorial e Meio Ambiente - Universidade de Araraquara, UNIARA. \\ ${ }^{*}$ Docentes do Programa de Pós-Graduação em Desenvolvimento Territorial e Meio Ambiente Ambiente - Universidade de Araraquara, UNIARA.
}

${ }^{*}$ Autor para correspondência e-mail: jcintrao.mestrado@uniara.com.br

\section{Palavras-chave}

\section{Recursos Hídricos}

Tingimento

Produção mais Limpa $(\mathrm{P}+\mathrm{L})$

Denim

\section{KEYWORDS}

Water resources

Dyeing

Cleaner Production

Denim

\begin{abstract}
RESUMO
A indústria têxtil utiliza recursos hídricos em seus processos produtivos. Dentre eles, o tingimento é um dos responsáveis pelo excessivo consumo de água, energia e geração de águas residuais, e o não gerenciamento dessa atividade causa impactos ao meio ambiente. O crescimento da demanda de água nos últimos anos pela atividade têxtil tem aumentado o seu consumo e, por consequência, as reservas hídricas indicam sinais de escassez, além da movimentação do ecossistema em direção ao estresse hídrico. Nesse contexto, uma abordagem que se apresenta como alternativa para melhoria da eficiência de processos tanto com relação à redução da emissão de poluentes quanto na geração de alternativas que envolvam reciclagem e reúso de recursos é a Produção mais Limpa $(\mathrm{P}+\mathrm{L})$. O objetivo deste trabalho é investigar a implantação da $\mathrm{P}+\mathrm{L}$ na etapa de tingimento do denim (tecido que produz o jeans) em uma indústria têxtil de grande porte do interior do Estado de São Paulo, a fim de entender o processo de adoção da $\mathrm{P}+\mathrm{L}$ e os resultados gerados. Quanto ao método de desenvolvimento desse trabalho trata-se de uma pesquisa qualitativa apoiada em pesquisa bibliografica e no desenvolvimento de um estudo de caso na empresa citada. O trabalho em campo possibilitou entender a utilização das ferramentas de gestão $\mathrm{P}+\mathrm{L}$ na etapa de tingimento do denim e permitiu também avaliar alternativas de redução do consumo de água, energia e geração de águas residuais adotadas pela empresa a partir da gestão e controle de sua estação de tratamento de águas residuais em concordância com os controles da CETESB (Companhia Ambiental do Estado de São Paulo). Após a utilização da abordagem de gestão $\mathrm{P}+\mathrm{L}$ na empresa estudada, verificou-se uma redução de consumo diário de água de $21 \mathrm{~m}^{3}$ para $16 \mathrm{~m}^{3}$ uma redução de aproximadamente $23,8 \%$.
\end{abstract}

\begin{abstract}

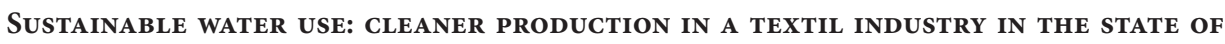
São Paulo

The textile industry uses water resources in its production processes. Among them, dyeing is one of the factors responsible for the excessive consumption of water, energy and wastewater generation, and the failure to manage this activity impacts the environment. The growth in the demand for water in recent years by the textile activity has increased its consumption and, as a consequence, water reserves indicate signs of scarcity, in addition to the movement of the ecosystem towards water stress. In this context, an approach that presents itself as an alternative to improve the efficiency of processes both in terms of reducing pollutant emissions and in the generation of alternatives that involves recycling and reuse of resources is Cleaner Production. The objective of this research is to investigate the implementation of cleaner production in the denim dyeing stage (material that produces jeans) in a large textile industry in the interior of the State of São Paulo, an end of understanding the process of adopting cleaner production and the results generated. As for the method of development of this work, it is a qualitative research supported by bibliographical research and
\end{abstract}


the development of a case study in the mentioned company. The field research made it possible to understand the use of cleaner production management tools in the denim dyeing stage and also alowed to evaluate alternatives for reducing water and energy consumption and generation of wastewater adopted by the company from the management and control of its wastewater treatment plant in accordance with CETESB controls (Companhia Ambiental do Estado de São Paulo). After using the cleaner production management tool in the studied company, there was a daily reduction water consumption from $21 \mathrm{~m}^{3}$ to $16 \mathrm{~m}^{3}$, a reduction of approximately $23.8 \%$. At the end, environmental chambers with techniques and manuals of procedures in the textile dyeing stages and environmental certifications were considered.

\section{INTRODUÇão}

O setor têxtil tem uma grande importância para a sociedade pelos fatores econômicos, históricos e por estar presente não apenas no vestuário, mas também, nos têxteis funcionais, na área da saúde, como válvulas cardíacas e materiais hospitalares descartáveis, e nos geotêxteis que são muito utilizados nas estruturas de estradas, pontes e asfalto.

As atividades têxteis utilizam uma quantidade excessiva de recursos hídricos em seus processos produtivos, especificamente nas etapas de acabamento e tingimento que dependem diretamente da água para sua realização. A demanda pelo consumo de água nesses processos está relacionada ao tipo de material tingido e finalizado. Tem uma expressiva importância para a economia brasileira e mundial, e a água e seu elevado consumo, que se constitui um recurso fundamental para a produção têxtil, é o principal contribuinte à degradação do meio ambiente.

Consequentemente, a indústria têxtil é reconhecida como uma das principais poluidoras do meio ambiente, em decorrência da cadeia produtiva complexa e diversificada. Os impactos negativos gerados ao meio ambiente e a sustentabilidade dos negócios, direcionaram as empresas a adotarem ferramentas de produção e estratégias ambientais, tais como a Produção mais Limpa (P+L) (CNI,2012).

A Produção mais Limpa $(\mathrm{P}+\mathrm{L})$ é um processo de gestão que abrange vários níveis da empresa, é também uma mudança cultural que trata da melhoria da eficiência de processos. Esse sistema reúne um conjunto de estratégias, práticas e condutas econômicas, ambientais e técnicas que podem evitar ou reduzir a emissão de poluentes no meio ambiente, por meio de ações preventivas, ou podem criar alternativas para que eles sejam reciclados ou reutilizados (CNI, 2012).

Essas práticas têm sido efetivas nos setores de fiação, tecelagem, beneficiamento, tingimento, estamparia e confecção, com o objetivo de minimizar resíduos e poluentes.

Frente ao consumo exacerbado de água, as indústrias têxteis no mundo, utilizam as estratégias de $\mathrm{P}+\mathrm{L}$. Ela é uma ferramenta de gestão ambiental vista como uma forma de adquirir vantagens competitivas, fatores sociais econômicos e políticos, que visam o desenvolvimento sustentável que é uma mudança não apenas nos sistemas de produção, mas também nos padrões de consumo (NIINIMAKI; HASSI, 2011).

No ano de 1989, o Programa das Nações Unidas para o Meio Ambiente (PNUMA), United Nations Enviromental Program (UNEP), introduziu o conceito de $\mathrm{P}+\mathrm{L}$ para defnir a aplicação contínua de uma estratégia ambiental preventiva e integrada que envolvesse processos, produtos e serviços, de maneira que se previssem ou reduzissem os riscos de curto ou longo prazo para o ser humano e o meio ambiente (SEIFFERT, 2009).

A introdução da P+L no Brasil contou com o apoio fnanceiro da ONUDI (Organização das Nações Unidas para o Desenvolvimento Industrial) / PNUMA (Programa das Nações Unidas para o Meio Ambiente). Essa ação fez parte do programa de implementação dos dez primeiros centros distribuídos 
por vários países em desenvolvimento e foi iniciado por meio do CNTL (Centro Nacional de Tecnologias Limpas), no Estado do Rio Grande do Sul, em 1995.

Dentre as vantagens de se adotar uma $\mathrm{P}+\mathrm{L}$ na indústria têxtil está a redução dos custos na produção, como consumo de energia e água, aumento da eficiência no processo produtivo, aumento da competitividade no mercado, redução de acidentes ambientais, melhoria nas condições de saúde e segurança do trabalhador, diversificação da amplitude de atuação no mercado interno e externo e melhorias no relacionamento com os órgãos ambientais. Logo, a $\mathrm{P}+\mathrm{L}$ proporciona ações preventivas com a finalidade de minimizar o impacto ao meio ambiente e evitar que se realizem ações somente na saída do sistema produtivo (CETESB, 2009).

As estratégias da $\mathrm{P}+\mathrm{L}$ se aplicam a produtos, processos e serviços e incluem procedimentos essenciais que a inserem nos processos de produção. Um bom diagnóstico do setor é fundamental para que o processo seja eficiente e se verifique a viabilidade técnica econômica de adoção dessa prática (CNI, 2012).

Dentro da $\mathrm{P}+\mathrm{L}$ para redução, recuperação e reutilização da água, podem-se instalar equipamentos controladores de fluxo e válvulas automáticas de controle de máquinas; estudar a possibilidade de combinar diferentes tratamentos em um único processo; instalar maquinário de baixa e ultra baixa vazão nos banhos; melhorar a eficiência de lavagem em banhos e processos contínuos; reutilizar água de resfriamento; e pesquisar as diversas possibilidades de reúso da água e aproveitamento da água da chuva (CETESB, 2009).

O objetivo da $\mathrm{P}+\mathrm{L}$ é atender de maneira sustentável às necessidades, usando com eficiência os recursos e energias renováveis, conservando a biodiversidade, utlizando a menor quantidade de matéria-prima e gerando a menor quantidade de resíduos (ARAÚJO, 2004).

Em consequência das projeções negativas relacionadas à disponibilidade de água, a legislação tornou-se ainda mais limitante, introduzindo constantemente padrões específicos para o enquadramento de corpos de água, assim como condições e padrões para o lançamento de efluentes legalizadas pelas Resoluções CONAMA 357/2005 e 396/2008 (ANA, 2018).

No contexto industrial, as incorporações de práticas que permitam o reusam da água se torna cada vez mais urgente, não apenas para satisfazer as regulamentações da legislação, mas também para diminuir o seu consumo e minimizar os custos de produção. Essas necessidades são substanciais na área de beneficiamento têxtil, pois o consumo médio de água costuma atingir valores de aproximadamente 160 $\mathrm{m}^{3}$ por tonelada de fibra processada, principalmente nas operações de branqueamento, mercerização, tingimento e lavagem (CAPAR et al., 2008).

Essa pesquisa teve por objetivo verificar a implantação da ferramenta de gestão $\mathrm{P}+\mathrm{L}$ na etapa de tingimento do denim e avaliar possíveis alternativas de redução do consumo de água, energia e geração de águas residuais em uma indústria têxtil de grande porte localizada no interior de São Paulo a fim de entender o processo de adoção da $\mathrm{P}+\mathrm{L}$ e os resultados gerados.

Para atingir o objetivo proposto o trabalho se baseia em pesquisa bibliográfica e no desenvolvimento de um estudo de caso na empresa citada. Ao desenvolver essa pesquisa alguns aspectos investigados e que serão descritos nesse artigo são: o desenvolvimento da $\mathrm{P}+\mathrm{L}$ na indústria têxtil; a relevância da indústria têxtil no Brasil, a investigação na empresa desse estudo e, por fim, os resultados e considerações finais.

\section{Métodos}

Esta seção tem o intituito de classificar essa pesquisa com relação aos métodos adotados e apresentar os passos para seu desenvolvimento.

O presente estudo trata-se de uma pesquisa qualitativa com o desenvolvimento de um estudo de caso em uma empresa textil localizada no interior do Estado de São Paulo. Segundo Yin (2001) o estudo de 
caso é a estratégia escolhida para se examinar acontecimentos contemporâneos e não se pode manipular comportamentos relevantes.

Os procedimentos operacionais seguidos foram baseados nas orientações de Miguel (2007). Resumidamente:

a) Definição da estrutura teórico conceitual: envolve a pesquisa bibliográfica que apoiou a condução desse trabalho, tanto na fundamentação dos conceitos e ferramentas da $\mathrm{P}+\mathrm{L}$ quanto no levantamento de trabalhos que a aplicaram na indústria têxtil;

b) Planejamento do caso: alguns aspectos essenciais nessa fase foram a seleção da empresa e da unidade de análise (no caso a área de tingimento do denim) e o planejamento da coleta de dados;

c) Coleta e análise dos dados: essa fase refere-se a execução propriamente dita, no caso as visitas técnicas para coleta de dados, com os roteiros de observação e questões previamente preparados na etapa anterior.

Algumas informações com relação a empresa escolhida é que se trata da quinta maior produtora de denim no Brasil. Essa companhia possui um parque industrial verticalizado com uma produção anual de 70 milhões de $\mathrm{m}^{2}$ de denim, segundo dados da BDO BRASIL, 2017. Na sua unidade industrial a empresa possui o processo de tingimento do denim, através do corante índigo, cujo processo requer uma quantidade abundante de água para a sua realização.

Com relação ao roteiro de observação utilizado na coleta in loco o foco foi investigar quais as ações da empresa referentes à estratégia de utilização da ferramenta de gestão $\mathrm{P}+\mathrm{L}$, em quais etapas do processo produtivo de tingimento havia maior urgência na melhoria contínua das ações e/ou em que etapas havia dificuldade de obtenção e continuidade da P+L.

Os dados levantados foram analisados tendo como parâmetro os manuais da CETESB que sugerem procedimentos e técnicas de $\mathrm{P}+\mathrm{L}$ com o intuito de reduzir o consume excessivo de água na indústria têxtil, eficiência do processo produtivo e redução de custos.

\section{Desenvolvimento da P+L em indústrias têxteis \\ Cenário Internacional}

Esta seção apresenta trabalhos que tratam do consumo de água na indústria têxtil, mais especificamente, pesquisas na Turquia, China, Áutria e Finlândia que são países em que essse segmento é de grande relevância.

A contribuição da indústria têxtil turca para a produção mundial de têxteis e confecções, é de cerca de $4 \%$, classificando o país em oitavo lugar em todo o mundo (TMOSIT, 2012). Esse país ocupa o $3^{\circ}$ lugar na exportação têxtil e de vestuário para os países da União Europeia (UE), $7^{\circ}$ lugar na produção de algodão, $4^{\circ}$ lugar no consumo de algodão, $5^{\circ}$ grau na produção de fios de fibra e $4^{\circ}$ posto em fios abertos produção no mundo. Além disso, a Turquia tem o segundo lugar na produção de algodão orgânico (MOIT, 2012).

Segundo o Instituto de Estatística da Turquia - TSI (2008), a indústria têxtil e de vestuário é responsável por $15 \%$ do consumo industrial de água (191,5 milhões de $\left.\mathrm{m}^{3}\right)$, o que o torna o $2^{\circ}$ maior consumidor industrial de água em todo o setor manufatureiro turco.

Um estudo de produção sustentável com alternativas de $\mathrm{P}+\mathrm{L}$ em uma indústria têxtil turca foi considerado um exemplo bem sucedido de adoção de prevenção e controle da poluição, com realizações 
econômicas e ambientais. (ALKAYA; DAMIRER, 2014). As vantagens econômicas obtidas nessa indústria com a implementação da produção sustentável, indicaram a redução dos custos de produção e de instalações caras, que fazem o controle de poluição no final da tubulação.

Além disso, os impactos na saúde e no meio ambiente dos trabalhadores das fábricas têxteis e da comunidade do entorno também foram reduzidos. As conquistas através de abordagens de produção sustentáveis foram inúmeras, por exemplo, economias de água entre 15\% e 79\% (COMISSÃO EUROPEIA, 2003; NCDENR, 2009; SHAIKH, 2009).

Ao investigar os benefícios ambientais e econômicos em uma indústria de fabricação de tecidos em Bursa, na Turquia (MOIT 2012), verificou a aplicabilidade de diferentes medidas de produção sustentável no setor têxtil, pois devido ao uso excessivo de água, energia, vapor e produtos químicos, corantes em processos úmidos, a indústria têxtil produz vários tipos de resíduos, incluindo principalmente as águas residuais, resíduos sólidos, gases e emissões de calor. As águas residuais dos processos têxteis contêm cargas significativas de matéria orgânica, sais e corantes.

Na avaliação de Alkaya e Damirer (2014), em uma empresa em Isparta na Turquia, o controle de prevenção da poluição no processo de tingimento da fibra de lã indicou que os consumos médios de água nos processos de tingimento, acabamento e geração de vapor foram de $74 \%$ e $17 \%$ do consumo total de água, respectivamente. Além disso, as águas residuais provenientes de processos de tingimento e acabamento constituíam $80 \%$ do fluxo total de águas residuais, cuja destinação final era o esgoto.

A poluição da água oriunda da indústria têxtil tornou-se um grande problema na Turquia. A atividade têxtil na bacia do Ergene provocou alterações drásticas na qualidade da água e reduziu o nível das águas subterrâneas, nos campos do aquífero. Além disso, a indústria têxtil turca consome muita energia e emite elevadas quantidades de $\mathrm{CO}_{2}$ (gás carbônico) (ALKAYA; DAMIRER, 2014).

Focando agora a China há crescentes problemas ambientais nesse país, a $\mathrm{P}+\mathrm{L}$ foi implementada em todas as regiões. Os governos regionais chineses desempenharam um papel de liderança para promover a implementação da $\mathrm{P}+\mathrm{L}$ através de medidas que incluem a coordenação das partes interessadas, o apoio financeiro, a estipulação de políticas adequadas e a realização de programas de capacitação. (BAI et al, 2015).

A $\mathrm{P}+\mathrm{L}$ é uma estratégia para reduzir os impactos ambientais, minimizar a poluição em sua origem nos processos produtivos resultando em um incremento na competitividade das empresas. É uma estratégia ambiental preventiva, cuja participação voluntária e outros incentivos positivos têm sido amplamente utilizados para incentivar as indústrias a implementarem essa ferramenta em todo o mundo. No entanto, levando em consideração características específicas da indústria têxtil e novos requisitos de gestão ambiental na China, a Lei de Promoção da $\mathrm{P}+\mathrm{L}$ propõe o uso de auditorias obrigatórias como medidas inovadoras para o avanço dessa ferramenta de gestão ambiental (BAI et al, 2015).

A China encontrou desafios significativos na melhoria em larga escala do desempenho ambiental das indústrias têxteis. Fatores como a dificuldade de incorporar os recursos institucionais, financeiros e técnicos, das pequenas e médias empresas, impediram eventuais adoções das estratégias de P+L. (BAI et al, 2015).

Como o sexto maior setor da indústria de consumo de energia na China, a indústria têxtil enfrenta grandes desafios na redução das emissões de gases de efeito estufa (HUANG et al., 2016).

Os fabricantes industriais são obrigados a adotar tecnologias de conservação de água e controle de poluição devido à crescente escassez de água, especialmente na indústria têxtil. Para auxiliar os produtores têxteis chineses, Lizhu Chen, et al. (2016) desenvolveram algumas estratégias de avaliação de desempenho de controle e conservação de água, utilizando as ferramentas de gestão $\mathrm{P}+\mathrm{L}$.

Essa ferramenta inclui a redução de três indicadores: remoação, consumo e aproveitamento de água. 
A técnica de reutlização de efluentes de baixa poluição em uma fábrica de tingimento de flanelas de poliéster demonstra que é possível tomar medidas de melhorais específicas de controle de poluição aos fabricantes do setor têxtil.

Quanto à Áustria a P+L utilizando o método russo TRIZ (Teoria da Resolução de Problemas Inventivos), foi aplicada em várias empresas para resolver diferentes problemas, dentre elas Procter \& Gamble, Ford Motor Company, Boeing, Philips Semiconductors, Samsung, LG Electronics. Essa metodologia TRIZ oferece ferramentas para desenvolver ações de melhoria de processos, sem a necessidade de conhecimento tecnológico específico sobre o processo que deve ser melhorado. Essa formulação de produção mais limpa usando as definições do TRIZ pode levar a uma definição mais genérica do conceito de $\mathrm{P}+\mathrm{L}$, em comparação se usadas apenas às estratégias da ferramenta de gestão ambiental (FRESNER, 2010).

$\mathrm{Na}$ Áustria, um levantamento dos últimos dez anos realizado na Graz University of Technology mostrou que as ações de $\mathrm{P}+\mathrm{L}$ preventivas em comparação com a eliminação de resíduos e as tecnologias de ponta, oferecem vantagens e que, em vários casos, o consumo de água por unidade de produção das indústrias do setor de tratamento de superfície, do processamento de alimentos e da indústria têxtil poderia ser reduzido em $30-90 \%$. Dessa maneira, o consumo de materiais foi reduzido entre $30-50 \%$ e o consumo de energia dos processos entre 15-25\%. O retorno dos investimentos fora recuperado em menos de um ano e as medidas foram efetivamente benéficas para as empresas (FRESNER et al., 2010).

Ao comparar as estratégias de produção mais limpa com as leis da evolução da metodologia TRIZ, encontrou novas alternativas de $\mathrm{P}+\mathrm{L}$, dentre elas: fluxos de resíduos, geração de águas residuais, consumo de energia e emissões, incluindo processos auxiliares (como geração de vapor, compressão de ar, tratamento de água). O foco foi selecionar matérias-primas que reduzissem a interação humana, identificando possibilidades de controle automático ideais (ar, água, materiais biogênicos), melhorando assim a eficiência do processo. (FRESNER et al., 2010).

Abordando agora pesquisa na Finlândia, de acordo Niinimaki e Hassi (2011), o volume da produção industrial de têxteis e vestuário mudaram dramaticamente ao longo dos anos na Finlândia. A produção de vestuário caiu 60\% no período entre 1998 e 2008. Ao mesmo tempo, a importação de vestuário aumentou 57\%. Essa é uma mudança notável, porque no período anterior de dez anos, 1988 e 1998, o volume de roupas importadas na Finlândia aumentou 44\%. Durante 1998 e 2008, o número de funcionários que trabalharam na indústria têxtil e vestuário caiu de 13.870 para 7.556. No entanto, no início da década de 1980, cerca de 70.000 pessoas trabalhavam na indústria têxtil e de vestuário na Finlândia.

Nos levantamentos de Niinimaki e Hassi (2011) as abordagens apontaram para as oportunidades de mudanças sustentáveis no setor têxtil e de confecção. Na Finlândia, o estabelecimento de um novo sistema de criação de valor é um pré-requisito para o redesenho de negócios mais sustentáveis nos mercados globais de têxteis e vestuário (NIINIMAKI; HASSI, 2011). O valor do produto definido durante o contexto de uso é o mais importante e deve estar profundamente conectado à satisfação do consumidor, bem como a vida útil dele. Repensar os fundamentos da criação de valor, importantes para o consumidor, podem oferecer oportunidades para desenvolver culturas sustentáveis tanto na produção, como no consumo.

De forma geral, com a abertura dos mercados globais, o acesso às novas tecnologias, produtos com preços mais acessíveis, foram disponibilizados em massa na economia setorial, aumentando o leque de opções por maquinários, tecidos e produtos confeccionados com valor agregado e preços altamente competitivos. Desta forma, os processos produtivos têxteis são inúmeros e sequenciais, utilizam muito recursos naturais como, por exemplo, a água, geram subprodutos úteis para outros setores da economia e empregam uma quantidade considerável de mão de obra.

\section{Cenário brasileiro}


O Brasil possui uma das cadeias têxteis mais completas do ocidente, com produção desde a fibra até os artigos confeccionados, além de ser o segundo maior empregador da indústria de transformação. No Brasil, as empresas formais totalizam 32 mil. Além disso, a nação brasileira é a $4^{\circ}$ maior produtora de malhas do mundo e o segunda maior de produtor de denim (tecido que produz o jeans) e ainda o $5^{\circ}$ maior produtor têxtil e o $4^{\circ} \mathrm{em}$ produção de peças do vestuário. O Brasil é o único país da América do Sul com posição de destaque na produção têxtil mundial. O país é responsável por $2,4 \%$ da produção mundial de têxteis, o que lhe garante a quinta posição no ranking mundial, e é o quarto maior produtor de vestuário com 2,6\% da produção mundial (GOTEXSHOW, 2017).

São Paulo possui uma população de 17 milhões e $1.500 \mathrm{~km}^{2}$ de área, é o maior centro comercial, industrial, financeiro e cultural no Brasil. É também um importante agrupamento da indústria têxtil, com mais de 300 fabricantes locais, o que contabiliza 60\% dos 500 maiores no Brasil (ABIT, 2017).

Uma das características da cadeia têxtil e de confecção brasileira é a existência de polos regionais de produção. Conforme ilustra a Figura 01 as principais regiões com grande desenvolvimento na indústria têxtil são a região Sudeste, São Paulo, Rio de Janeiro, Espírito Santo e Minas Gerais com um total de $49 \%$ nos diferentes elos da cadeia de produção têxtil, a região sul, Rio Grande do Sul, Santa Catarina e Paraná, correspondendo a $29 \%$ da produção brasileira, a região nordeste com $17 \%$ da produção do setor têxtil nacional e por fim as demais regiões brasileiras correspondem a $5 \%$ da produção de têxteis (GOTEXSHOW, 2017).

Figura 01 - Distribuição da Indústria nas Principais Regiões.

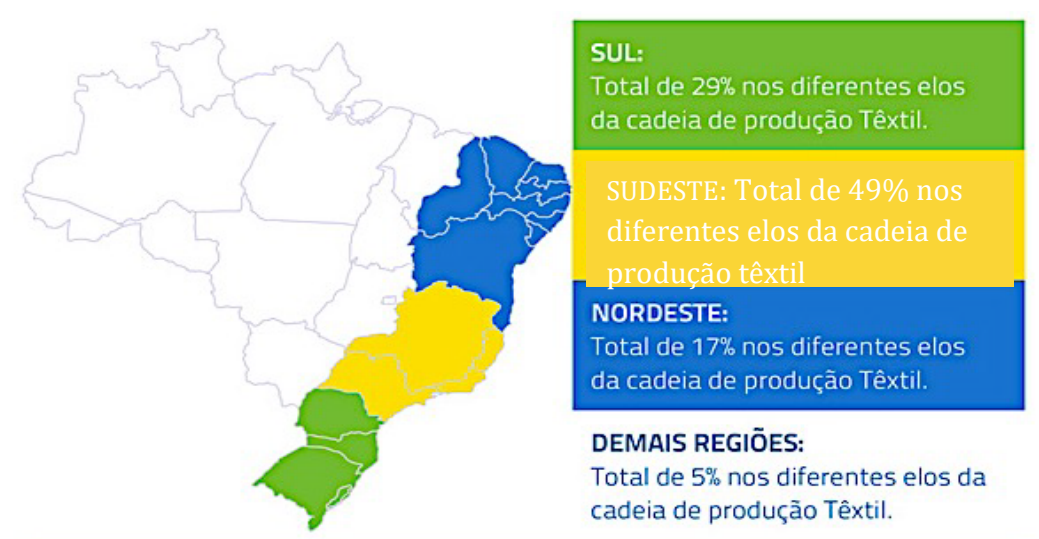

\begin{tabular}{|l|l|l|}
\hline SUL & SUDESTE & NORDESTE \\
- RIO GRANDE DO SUL $-3,2 \%$ & - SÃO PAULO $-29,0 \%$ & - CEARÁ $-7,0 \%$ \\
- SANTA CATARINA $-17,1 \%$ & - RIO DE IANEIRO $-6,4 \%$ & - RIO GRANDE DO NORTE - $2,9 \%$ \\
- PARANÁ $-8,8 \%$ & - ESPIRITO SANTO $-1,7 \%$ & - PARAÍBA $-1,3 \%$ \\
& - MINAS GERAIS $-11,5 \%$ & - PERNAMBUCO $-2,6 \%$ \\
& & - ALAGOAS $-0,1 \%$ \\
& & - SERGIPE $-0,7 \%$ \\
& & - BAHIA $-2,2 \%$ \\
\hline
\end{tabular}

Fonte: GOTEXSHOW, 2017.

O Brasil tem uma cadeia têxtil completa, desde a produção das fibras até a confecção de peças de vestuário. Tem grande participação na produção mundial de produtos têxteis e de vestuário. Na produção do denim está entre os 5 maiores produtores no mundo. 
O Sinditêxtil (Sindicato da Indústria Têxtil de São Paulo) lançou em junho de 2010, um manual de indicadores de desempenho ambiental. O objetivo era fazer com que as empresas adotassem critérios de produção mais sustentáveis e avaliassem a quantidade de água consumida e reutilizada, energia, carga orgânica, geração total de resíduos e resíduos recicláveis (SINDITÊXTIL, 2017).

Juruaia é uma cidade localizada no Sul de Minas e possui cerca de 10.500 habitantes, sua economia é voltada para a agropecuária, mas se destaca na fabricação e comércio de Lingerie. A cidade conta com mais de 250 empresas atuando na produção de lingerie, moda praia, pijamas adulto e infantil, moda fitness, cuecas entre outros artigos do ramo. Com uma área de $219 \mathrm{Km}^{2}$, Juruaia faz limites com as cidades de Nova Resende, Monte Belo, Muzambinho, Guaxupé e São Pedro da União.

A $\mathrm{P}+\mathrm{L}$ adotada nas indústrias têxteis no município de Juruaia - MG, mostrou que a Industria têxtil gera resíduos em grande volume. A maior parte dos resíduos causam impactos ambientais e o principal problema é a ocupação física de grande volume de resíduos em aterros, os quais levam anos e até décadas para serem degradados e absorvidos pela natureza (SELEGHIM; SILVA, 2016).

O município de Juruaia - MG enfrenta alguns problemas de viés ambiental, como por exemplo, desperdícios de resíduos têxteis, gerados, em sua maioria, devido a um planejamento ineficiente de criação da modelagem, corte, encaixe dos moldes, qualidade ou falta da padronização das matérias-primas. A mão-de-obra pouco qualificada, o maquinário sem manutenções preventivas, também são os causadores de resíduos gerados na confecção que ocupam grandes volumes e são descartados em sua maioria (SELEGHIM; SILVA, 2016).

$\mathrm{Na}$ análise do polo produtivo das quinze empresas em Juruaia - MG notou-se que elas todas geram resíduos, principalmente têxteis. Dentre eles foram verificados: restos de tecidos, cones de costura, plásticos e papeis. Observou-se, também, que a maioria dos resíduos são gerados principalmente no processo de corte, e na área de produção. Das quinze empresas pesquisadas 100\% responderam que não há nenhum tipo de fiscalização, nem por parte da prefeitura da cidade, muito menos por órgãos do governo e do meio ambiente. No caso da produção de resíduos gerados na indústria, a produção mais limpa é uma prática de fundamental importância para as organizações, já que ela busca essencialmente a otimização dos recursos, evitando produzir e dispor resíduos no meio ambiente (SELEGHIM; SILVA, 2016).

Seleghim e Silva (2016), através do levantamento na produção e destinação dos resíduos em quinze empresas do Arranjo Produtivo Local do setor de fabricação de lingerie, moda praia, fitness, cuecas, meias e pijamas em Juruaia-MG, principalmente, resíduos têxteis gerados por empresas deste segmento estudaram a viabilidade de implantação da metodologia de $\mathrm{P}+\mathrm{L}$ como ferramenta para o desenvolvimento sustentável para preservar o meio ambiente e diminuir custos operacionais.

Nesse estudo, algumas entrevistas foram realizadas com diretores, gerentes de produção e funcionários de corte e costura das empresas para examinar os levantamentos e informações referentes à caracterização dos resíduos gerados, os critérios de adequação das empresas, à seleção e auditoria de receptores, levantamento de dificuldades encontradas e noções relacionadas ao gerenciamento de resíduos. Das empresas pesquisadas nesse estudo foi observado pelos autores que todas geravam resíduos, principalmente têxteis; dentre eles foram contabilizados: restos de tecidos, cones de costura, plásticos e papeis. Verificaram também que a maioria dos resíduos são gerados principalmente no processo de corte, e na área produção. Das quinze empresas pesquisadas $100 \%$ responderam que não há nenhum tipo de fiscalização, nem por parte da prefeitura da cidade, muito menos por órgãos do governo e do meio ambiente.

No caso da produção de resíduos gerados na indústria, a $\mathrm{P}+\mathrm{L}$ é uma prática de fundamental importância para as organizações, já que ela busca essencialmente a otimização dos recursos, evitando produzir e dispor resíduos no o meio ambiente. Isso se dá devido a utilização de tecnologias modernas, bem como, da cons- 
cientização ambiental das organizações para com o meio em que estão inseridas (SELEGHIM; SILVA, 2016).

Zagonel e Schultz (2009) definiram quais as modificações necessárias para a minimização do uso de água no processo de tingimento e acabamento na Lajestre, uma indústria em Estrela, no Rio Grande do Sul.

Após análise do processo de tingimento os autores verificaram que é possível reutilizar em torno de 10.000 litros de água/dia. A água oriunda do resfriamento do tingimento de $130^{\circ}$ para $80^{\circ}$ e que circula na lavagem à frio, é limpa. Assim, existem alternativas para redução do consumo de água no processo de tingimento e acabamento têxtil, além da possibilidade de reutilizar o efluente líquido tratado com implementação de um sistema de recuperação de água.

Além disso, Zagonel e Shultz (2009) verificaram que existem alternativas para a redução do consumo de água no processo de tingimento e acabamento, neste setor que é um importante setor da economia brasileira e mundial, e o aumento do consumo de água é o principal contribuinte à degradação do meio ambiente.

As práticas de $\mathrm{P}+\mathrm{L}$ na indústria têxtil influenciam o processo produtivo de forma a torna-lo mais eficiente. São mensurados pela redução de custos e pela minimização da geração de resíduos líquidos e sólidos nas etapas do processo produtivo.

Não obstante a esses procedimentos de gestão ambiental, estão as medidas simples de adoção de alguns indicadores, que efetivamente trabalham na redução do consumo de água e na utlização desse recurso de forma mais consciente.

Nas empresas de tingimento têxtil que usam essencialmente quantidades elevadas de recursos hídricos é preciso que se aumente a taxa desse recurso natural, provenientes na maioria das vezes de poços artesianos, que tem licenças ou outorgas de funciomanento, a abundância de água utilizada é proporcional a necessidade da empresa, ou seja, capta-se a quantidade necessária de água na bacia hidrográfica.

As considerações anteriores foram introdutórias para uma análise mais profunda da $\mathrm{P}+\mathrm{L}$ no cenário internacional e nacional. No que diz respeito as utlizações das práticas de $\mathrm{P}+\mathrm{L}$ no mundo observou-se que além dos ganhos em produtividade, existem benefícios tangíveis do ponto de vista econômico e ambiental que engajam as empresas como ecologicamente corretas, politicamente viáveis e socialmente aceitas garantindo a elas uma posição de destaque sustentável, e sem dúvida, minimizando os danos e impactos ao meio ambiente.

\section{Produção mais limpa em uma indústria têxtil do Estado de São Paulo}

Essa seção irá descrever o estudo de caso e foi organizada de forma a abordar em um primeiro momento o universo da pesquisa, após detalha-se o processo produtivo do denim, na sequencia se apresenta o tratamento de efluentes e as características da água residual e, por fim, as portencialidades do reúso da água na fase do tingimento.

\section{CARACTerização do universo da PEsquisa}

A indústria têxtil em estudo iniciou as atividades de produção do denim em 1980 e atualmente é uma das mais modernas empresas no setor de tecelagem. Possui quatro unidades localizadas no interior de São Paulo, Rio Grande do Norte e Santa Catarina. A empresa está entre as cinco maiores empresas brasileiras produtoras de denim, com um lucro líquido de $\mathrm{R} \$ 59.500$ milhões e uma produção de $\mathrm{R} \$ 328$ milhões (BDO BRAZIL, 2017).

Nessa fábrica, o processo de produção têxtil inicia-se pela fiação que é a etapa em que a pluma de algodão é transformada em fio. Os fios são colocados em gaiolas e posteriormente passam pela urdideira (uma máquina que dispõe os fios de forma orientada para que possam ser tecidos). Após a urdição os tecidos são tramados e tingidos. 
Karisma et al. (2017), fizeram uma estimativa de que $1 \mathrm{~kg}$ de tecido consome de 60 a 100 litros de água e geram resíduos líquidos que são cerca de 2 a 180 litros de águas residuais por quilo de produto têxtil produzido.

Por essa razão a indústria têxtil foi selecionada para a pesquisa de campo, pois além de possuir o processo produtivo completo, da matéria prima até a transformação em tecido, possui a unidade de tingimento que é uma das etapas que mais consome água no processo produtivo, além de gerar grandes quantidades de águas residuais.

A empresa trabalha com a Lean Manufacturing um modelo de gestão que surgiu na Toyota Motor Company em que o principal objetivo é fornecer produtos de alta qualidade, com o menor custo possível, dentro do menor tempo, através da eliminação de desperdícios. O lean manufacturing se baseia em uma abordagem para identificar e eliminar o desperdício com melhoria contínua, fluxo de material puxado, sempre buscando a qualidade total. O contexto de desafios dessa metodologia e mudanças requer colaboradores motivados, satisfeitos e comprometidos, uma vez que eles são fundamentais no processo de desenvolvimento organizacional (GESTÃO INDUSTRIAL, 2018).

A água residuária têxtil oriunda de processos de tingimento possui corantes com alto peso molecular e baixa biodegradabilidade segundo Dasgupta (2015), por isso seu lançamento nos cursos de água causam um grande impacto. A remoção de cor por ozonização, oxidação por peróxido de hidrogênio ou UV e técnicas de eletroquímica não são adequadas, visto que os corantes têxteis possuem uma estrutura aromática molecular complexa que resiste a degradação (FERSI; GZARA; DHAHBI, 2005).

Assim sendo, o consumo exacerbado de recursos hídricos na indústria têxtil também gera uma grande quantidade efluentes têxteis, que normalmente possuem uma carga elevada de produtos químicos. A presença de corantes sintéticos e altos teores de metais como cádmio, cromo, cobre, chumbo, mercúrio e zinco, assim como sais, surfactantes, sulfetos, solventes, além da coloração e de elevados índices de acidez (SOTTORIVA, 2002).

As águas residuais geradas nos processos produtivos têxteis não devem ser decartadas no meio ambiente sem que passem por um tratamento, que habitualmente, se baseiam na legislação ambiental vigente do Conselho Nacional de Meio Ambiente (CONAMA) como a Resolução número 430 de 13 de maio de 2011 e em normas como a ABNT 13.969 de 1997. Essas águas oriundas do tingimento possuem elevada carga orgânica e cor acentuada o que dificulta a passagem da radiação solar nos cursos de água, comprometento a realização da fotossíntese, aumentando a toxicidade nesses ambientes aquáticos e levando a contaminação do meio ambiente.

Dessa forma, a empresa segue a legislação e os mecanismos mencionados pelos orgãos competentes como o IBAMA, CETESB e CONAMA, como por exemplo, a Resolução do o CONAMA número 430 de 13 de maio de 2011, que sugere que as águas residuais tenham descoloração após o tingimento e que se reduza tanto a toxicidade como a carga química presente nessas águas de transbordo que serão também tratadas pela rede de saneamento básico da cidade. Assim também como sugerido nos manuais de $\mathrm{P}+\mathrm{L}$ da CETESB e baseado nas técnicas e procedimentos para redução do consumo de recursos naturais e geração de efluentes. A empresa não disponibilizou a ánalise dos efluentes líquidos, mas de acordo com a entrevista e observação in loco do processo produtivo foi possível checar que a empresa trata suas águas residuais e efluentes líquidos seguindo os padrões propostos na legislação de redução de carga química, coloração da água e reutilização.

A $\mathrm{P}+\mathrm{L}$ é uma das intercorrências utlizadas para tornar os processos produtivos mais eficientes e eficazes, reduzindo os impactos ambientais e custos operacionais, como água e energia, por exemplo, além de diminuir o dispêndio de água limpa. 
Nesse sentido, observa-se que as ações da empresa em estudo estão previstas na legislação ambiental vigente e seguem índices de manuais de implementação de tecnologias mais limpas. O que de fato existe é um cumprimento da obrigatoriedade da empresa enquanto instituição e não da consciência ou engajamento ambiental.

Os ganhos ambientais e econômicos segundo MOIT (2012), mostram a aplicabilidade de diferentes medidas de produção sustentável nessa empresa do setor têxtil, pois devido ao uso excessivo de água, energia, vapor e produtos químicos, corantes em processos úmidos, essa indústria produz vários tipos de resíduos, incluindo principalmente as águas residuais que contêm cargas significativas de matéria orgânica, sais, corantes, resíduos sólidos, gases e emissão de calor.

Otimizar recursos naturais, reduzir o consumo desenfreado de água nas etapas de tingimento do denim, avaliar potenciais de reúso e o tratamento de águas residuais deve ser uma condição diária e pré-requisito de qualquer outra empresa optante pela mesma atividade têxtil e a $\mathrm{P}+\mathrm{L}$ deve ser uma prática habitual.

As técnicas operacionais propostas pela CETESB para minimizar os fardos poluidores recorrentes dos processos produtivos, visam justamente otimizar o tratamento de efluentes líquidos e de fato, isso influenciará no rendimento do tratamento. Ademais, as câmaras ambientais mencionadas na seção I objetivam o intercâmbio de ações do setor têxtil para que sejam gerados tráfego de informações ecossistêmicas entre as empresas que exercem a mesma atividade.

As metodologias propostas pela CETESB preveem a moderação do consumo da água no processo de tingimento através do processo em contra corrente permitindo que o material têxtil seja tratado sem interrupções no processo, de modo a armazenar o banho no processo sempre que possível, refazer a composição para reutilzação em um novo tingimento. Na realidade os meios produtivos são sugeridos pelos orgãos competentes do sistema ambiental.

Outra metodologia recomenadada pela companhia ambiental é a contenção do consumo de energia, empregando caldeiras alimentadas por combustão para que se desperdice menos energia elétrica nesse cenário de conflitos energéticos.

De uma forma ou de outra, tanto as metodologias como as licenças ambientais deveriam estar baseadas em um estudo do meio ambiente local produtivo. Sustentar-se como condição indispensável e efetiva. O que de fato não ocorre. Uma vez implementadas são renovadas a cada dois ou três anos, periodo mais que suficiente para a ocorrência de desastres ambientais, ecológicos comprometendo não só o meio ambiente, mas as condições favoráveis para a qualidade do ar e de vida das comunidades do entorno.

\section{Processo Produtivo do Denim}

Para o funcionamento do processo de tingimento do denim é imprescindível a utilização da água. Dessa forma, a empresa, objeto de estudo, tem três poços artesianos, um deles desativado. Os poços artesianos possuem certidões de funcionamento, e nesse ano solicitaram a perfuração de mais uma unidade, que provavelmente será utilizada no processo de lavanderia, recurso muito utilizado para gerar valor agregado ao jeans bruto.

A outorga de poços artesianos é um instrumento que assegura legalmente ao empreendedor o direito de uso das águas subterrâneas disponíveis na sua bacia hidrográfica. O certificado de outorga garante o direito de captar a quantidade de água necessária para um empreendimento, evitando multas e punições (CONCEITO AMBIENTAL, 2015).

Dessa forma, foi constatado que o recurso hídrico natural, além de abundante é muito barato, na verdade não se paga por ele. Qualquer sugestão de implementação de tratamentos de efluentes ou melhorias em processsos produtivos não é justificado pela economia no consumo de água, já que não se 
tem um custo efetivo por esse recurso, apenas outorgas de exploração de poços artesianos. Enquanto esse recurso não for um artigo caro e pago nenhum investimento com tratamentos de efluentes será viável.

Atualmente, a indústria trabalha apenas com o denim bruto e tem metas e projetos para trabalhar com lavanderia e estonagens (processos de acabameto que conferem maior valor agregado ao tecido de jeans).

O processo produtivo do denim inicia-se quando os fios de algodão são dispostos em rolos de urdume de 12 a 14 rolos, ainda crus e passam pela urdideira, que tem por finalidade a paralelização dos fios para que haja uma maior uniformidade da cor durante o tingimento. Após esssa etapa são mercerizados, para que a maturidade da fibra de algodão seja aumentada, ou seja, para que o lúmen ou núcleo da fibra aumente de tamanho e haja maior absorção de corantes e solidez da cor. Na verdade, no processo de tingimento do denim tinge-se superficialmente os fios de urdume, o núcleo da fibra permanence natural ou cru. Em seguida, os fios são lavados e limpos através do enxágue, nas caixas de lavagem que geram as águas de transbordo. Essas águas residuais são tratadas na própria empresa por um sistema de tratamento físico-químico a fim de tornar a água o mais incolor possível.

Na sequência, os fios já tintos são elevados para oxidarem em contato com o ar, já que o índigo se encontra na forma reduzida que apresenta coloração esverdeada. A molécula do corante índigo é relativamente pequena e possui baixa afinidade com a fibra celulósica. Para uma boa eficiência de tingimento é necessário que o corante seja reduzido e também sejam realizadas uma série de impregnações e foulardagens (prensagens) de acordo com a Figura 02. A oxidação ocorre após o processo de tingimento, assim como o uso de produtos específicos que otimizarão a absorção de corantes pela fibra. Cada série de impregnação, foulardagem e oxidação é denominada ciclo de tingimento, que variam no geral de quatro a oito ciclos, dependendo da intensidade de coloração azul que se deseja obter. O número de caixas de tingimento depende da intensidade da cor, ou seja, poucas caixas de lavagem oferecem uma baixa intensidade e muitas caixas proporcionam uma alta vivacidade da cor.

Figura 02 - Ciclo de Tingimento e Oxidação do Índigo na Empresa em Estudo.

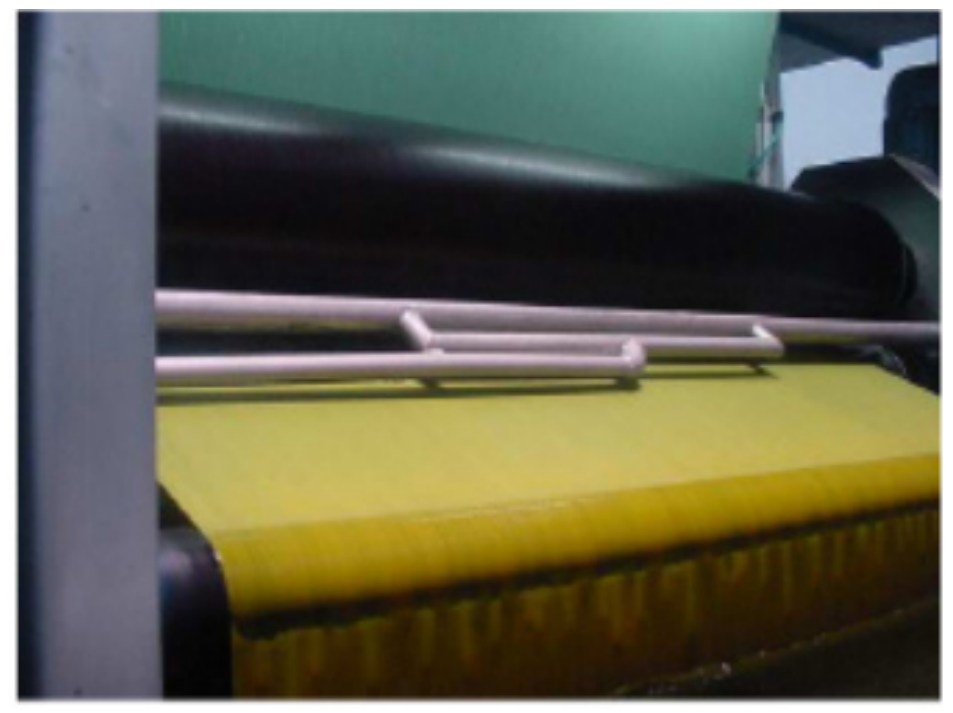

Fonte: Elaborado pelos autores, 2019.

A seguir na etapa de engomagem, a goma é adicionada sobre os fios com a finalidade de oferecer uma maior resistência à fibra, fortalecendo o fio para o processo de tecelagem, impedindo-o de romper ou 
quebrar com facilidade. Após essa etapa os fios são enrolados novamente em rolos a uma velocidade de 32 metros por minuto. Cada rolo de denim tem 8.640 metros e é envolto em papelões para posterioemente serem utilizados na tecelagem.

$\mathrm{Na}$ tecelagem os fios de urdume (fios dispostos no sentido vertical) já tintos formam a estrutura do tecido plano (conjunto de fios de urdume entrelaçados formando um ângulo reto de $90^{\circ} \mathrm{com}$ os fios de trama - fios dispostos no sentido horizontal) conferindo ao tecido uma estrutura resistente e mais rígida, denominado jeans, de acordo com a Figua 03.

Figura 03 - Tecelagem do Denim na Empresa em Estudo.

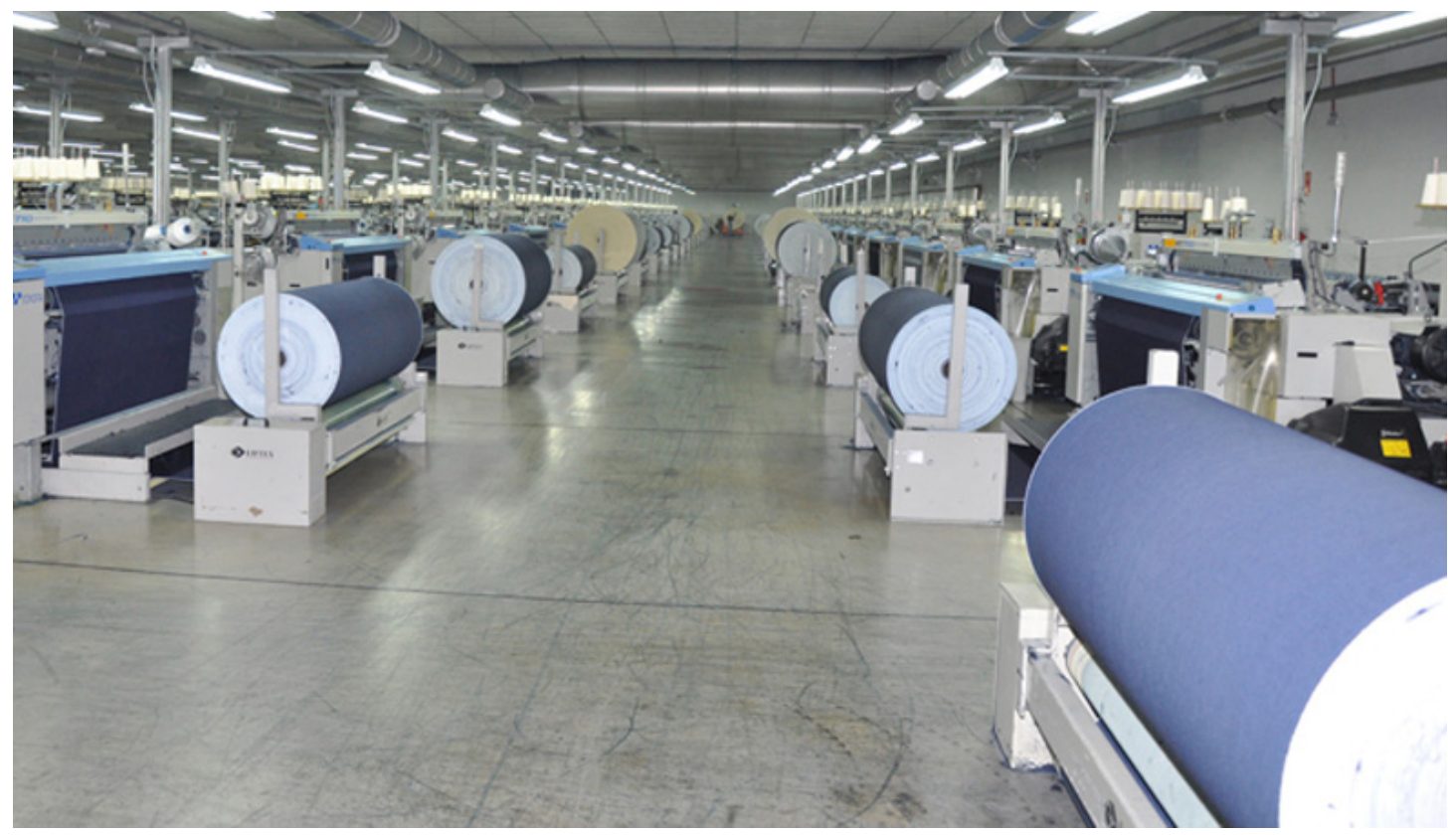

Fonte: Elaborado pelos autores, 2019.

Na etapa do tecimento do denim, conforme ilustra a Figura 03, os fios dispostos nos rolos de urdume e os teares trabalham de tal forma que os fios brancos são representados pela trama e os azuis pelo urdume que são tingidos e enrolados em bobinas grandes, chegando ao setor de tecelagem. No tear que os fios de urdume são encaixados com os fios da trama, e formam o tecido - ainda cru, sem acabamento e lavagem. Cada tipo de processo usado na tecelagem dos fios de denim é que determina a aparência característica do material. A parte interna possui uma cor clara, a parte externa é azul. Essas características ocorrem porque os fios da trama e os fios do urdume são tingidos juntamente. O tecido é estabilizado dimensionalmente através da sanforização que é um tratamento térmico especial em tambores de aço.

As águas de transbordo das caixas de lavagem são encaminhadas para a estação de tratamento físico química da empresa e funcionam por flotação de ar dissolvido. O potencial hidrogeniônico $(\mathrm{pH})$ indica a acidez ou neutralidade dos efluentes e é controlado no tanque de equalização. Com a adição de peróxido de alumínio e coagulante ocorre a coagulação, nesse momento o gradiente de velocidade é baixo. A água entra por na parte superior da tubulação na tonalidade azul bem escuro (tonalidade do índigo) e sai na tubulação por baixo levemente corada, quase transparente. A mistura inicialmente é rápida, conforme o gradiente de velocidade vai baixando a mistura levita formando-se as floculações. O polímero formado é resultado do floco grande mais o ar dissolvido. 
Na câmara de saturação o ar comprimido e a água sob pressão liberam micropartículas hidrofílicas (que se dissolvem em água) e aderem aos tanques. O sulfeto adicionado forma floquinhos e o ar empurra esses floquinhos formando o lodo, que desce pelo tanque de lodo. Após essa etapa, já no filtro de prensa, a água é liberada e o lodo seco e prensado é encaminhado para o aterro sanitário do município.

\section{Tratamento de EFLUENTE Físico-QUímico}

A água residuária proveniente do processo de tingimento segue para a ETAR (Estação de Tratamento de Águas Residuais) da indústria antes de ser lançada na rede de esgoto do munícipio do Estado de SP.

As características da água residuária, ligadas ao processo de tingimento, variam de acordo com o produto originado. O efluente gerado pela indústria chega a estação de tratamento por meio de dois coletores e recebe um tratamento por gradeamento com quarto grades de diâmetro descrescente. Após esse tratamento preliminar, o efluente segue para o tanque de equalização com volume útil de 112 metros e capacidade total de 244 metros. O objetivo desse tanque é tornar a vazão da água regular e uniformizar a água residuária. No tanque equalizador o $\mathrm{PH}$ da água é normalizado em torno de $9,0 \pm 0,5$, conforme Resolução 430 CONAMA de 2011, pela adição de ácido sulfúrico à $12 \%$ ou soda caustica, para que haja uma coagulação eficiente na etapa de mistura rápida (reator tubular instalado na canalização de recalque). Após a unidade de mistura rápida o efluente segue para floculação responsável por transformar o efluente em flocos. Parte do efluente floculado é encaminhada para o poço de sucção das bombas de recalque da câmara de saturação. Nessa câmara a água pressurizada é saturada de ar e removimentada para a unidade de flotação para que em bocais difusores seja despressurizada e produza microbolhas de ar que auxiliarão o processo de flotação, conforme demonstra a Figura 2.

A válvula do tipo bóia, instalada na câmara de saturação, controla o nível de água no poço de sucção das bombas de recalque para que o escoamento do efluente ocorra na direção do poço de sucção. O efluente gerado no flotador passa por uma calha parshal (um dispositivo tradicionalmente usado para medição de vazão em canais abertos de líquidos fluindo por gravidade, muito utilizado nas estações de tratamento de água) que mede e registra a vazão e segue para a rede coletora de esgoto. O lodo produzido no flotador é encaminhado para o reservatório de recepção de lodo, que abastece o sistema de desaguamento de lodo composto por uma bomba helicoidal, tanque de pressão e filtro prensa. O lodo prensado é armazenado em uma caçamba e encaminhado para o aterro sanitário industrial devidamente licenciado conforme demsontra a Figura 04.

Figura 04 - Diagrama representativo das águas residuais da indústria do estudo.

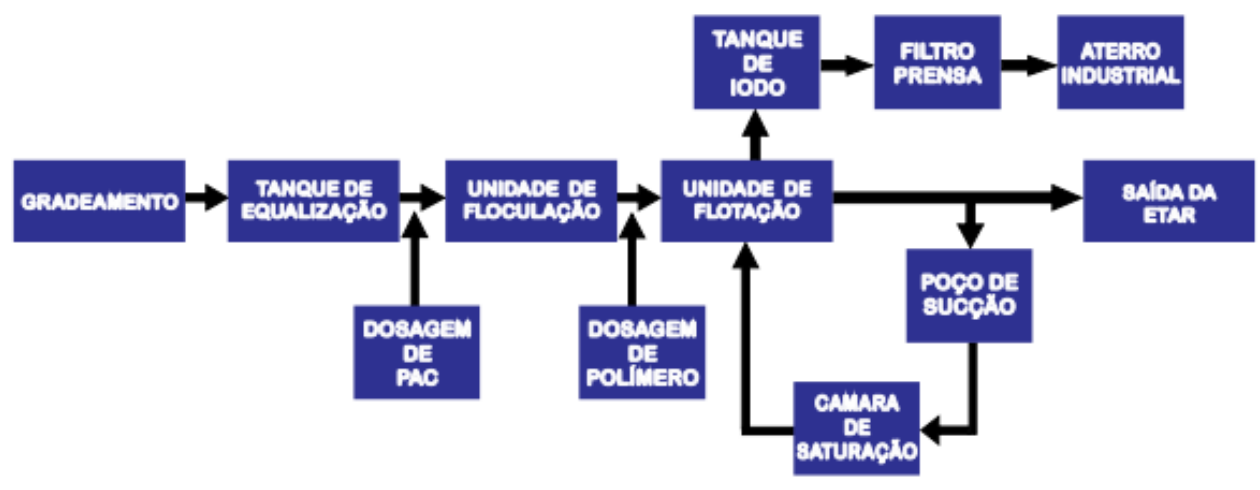

Fonte: Elaborado pelos autores, 2019. 


\section{Características da Água residuária têXTIL}

A água residuaria têxtil apresenta diferentes concentrações de químicos e dependendo do processo apresentará uma característica específica. Alguns pesquisadores estabelecem parâmetos para indicar a característica da água residual bruta, conforme a Figura 05, mas para cada estudo de caso é necessário que se adote um tratamento adequado. No caso da empresa em estudo são levados em consideração os índices de DBO (demanda bioquímica de oxigênio) e DQO (demanda química de oxigênio), além da temperatura das águas de desengomagem (remoção da goma) que estão em torno de 70 a $80^{\circ} \mathrm{C}$, dessa maneira interferem no tipo de tratamento e análise das águas residuais.

Figura 05 - Principais etapas do processo produtivo textile X características da águas residuárias geradas.

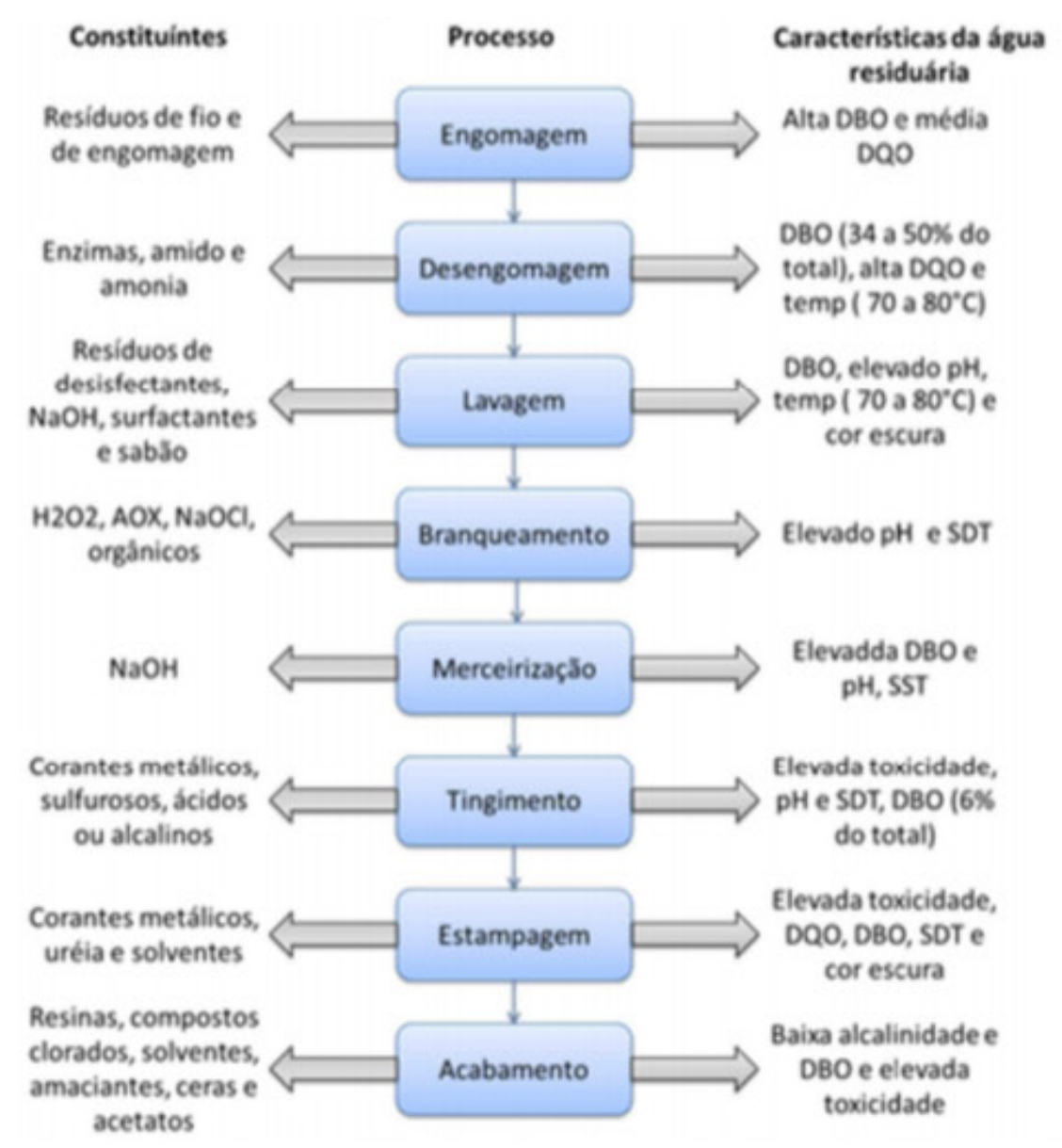

Fonte: Adaptado de VERMA; DASH; BHUNIA, 2012.

As águas residuárias, possuem carcterísticas e o tipo de tratamento e pós tratamento utilizado pelas indústrias não depende do custo da tecnologia, da legislação do país e/ou estado e da disponibilidade hídrica A caracterização das águas residuárias dos processos mais utilizados por indústrias têxteis está indicado na Tabela 01. 
Tabela 01 - Caracterização das águas residuárias dos processos texteis.

\begin{tabular}{|c|c|c|c|c|c|}
\hline Parâmetros & Lavagem & Branqueamento & Mercerização & Tingimento & Composto \\
\hline $\mathrm{pH}$ & $9-14$ & $8,5-11,0$ & $8,0-10,0$ & $1,5-10,0$ & $1,9-13,0$ \\
\hline SDT & $\begin{array}{c}12.000= \\
30.000\end{array}$ & $2500-11.000$ & $2000-2600$ & $1500-4000$ & 290010.000 \\
\hline SST & $1000-2000$ & $200-400$ & $600-1900$ & $50-350$ & $100-700$ \\
\hline Cor & $\cdot$ & - & Colorido & Muito colorido & $\begin{array}{c}\text { Extremamente } \\
\text { colorido }(>14.000 \\
\text { unidades } \mathrm{Pt}-\mathrm{Co})\end{array}$ \\
\hline DBO & $2500-3500$ & $100-500$ & $50-120$ & $100-400$ & $50-550$ \\
\hline DQO & $\begin{array}{c}10.000- \\
20.000\end{array}$ & $1200-1600$ & $250-400$ & $400-1400$ & $250-8000$ \\
\hline Cloretos & • & - & $350-700$ & - & $100-500$ \\
\hline Sulfatos & - & - & $100-350$ & - & $50-300$ \\
\hline
\end{tabular}

DBO - Demanda Bioquímica de Oxigênio

DQO - Demanda Química de Oxigêneo

Fonte: adaptado de Dasgota et al. (2015).

\section{Potencialidades de Reúso da ÁguA Residual do Tingimento}

O reúso é uma prática na empresa e acontece, conforme a Figura 06 que é o atual mapa de reúso das águas de tingimento da empresa, e os potenciais de reúso identificados na Figura 07. As águas de reúso são provenientes das águas de transbordo do tingimento que passam pelo tratamento físico químico de remoção de cor e carga química. Os poços artesianos abastecem a torre de resfriamento, o sistema de refrigeraçãoo da tecelagem, as caldeiras. Também abastecem o caso sanitário, preparo de alimentos e higiene pessoal. Há também um reservatório de águas da chuva que são utilizadas para resfriar os compressores e irrigação do jardim.

A empresa está utilizando as águas de reúso e o consumo diário estimado da planta industrial está conforme indicado na Tabela 2. Após a identificação dos principais pontos de reúso foi determinada a qualidade mínima requerida da água para cada um desses pontos. O maior consumo de água acontece nas caixas de lavagem no processo de tingimento do denim, em que os fios ou cordas são imersos no banho de tingimento e após sobem pelos foulards para oxidação prensados para remover o excesso de banho. Nessa etapa são geradas as águas de transbordo que posteriormente serão tratadas na estação físico química de tratamento.

A empresa está utilizando as águas de reúso e o consumo diário estimado da planta industrial está conforme indicado na Tabela 02. Após a identificação dos principais pontos de reúso foi determinada a qualidade mínima requerida da água para cada um desses pontos. O maior consumo de água acontece nas caixas de lavagem no processo de tingimento do denim, em que os fios ou cordas são imersos no banho de tingimento e após sobem pelos foulards para oxidação prensados para remover o excesso de banho. Nessa etapa são geradas as águas de transbordo que posteriormente serão tratadas na estação físico química de tratamento. As águas de reúso provenientes do tratamento físico químico são utilizadas na limpeza do piso e equipamento, no preparo de banho químico de tingimento, nas caixas de lavagem e no preparo da goma. Também são utilizadas nas caldeiras, torre de resfriamento e na irrigação do jardim. No vaso sanitário também foi adotado o sistema de reutilizar as águas tratadas provenientes do transbordo. A reutilização da água tratada gerou uma economia de aproximadamente 5000 litros de água por hora. 
Figura 06 - Representação do uso atual da água na empresa estudada.

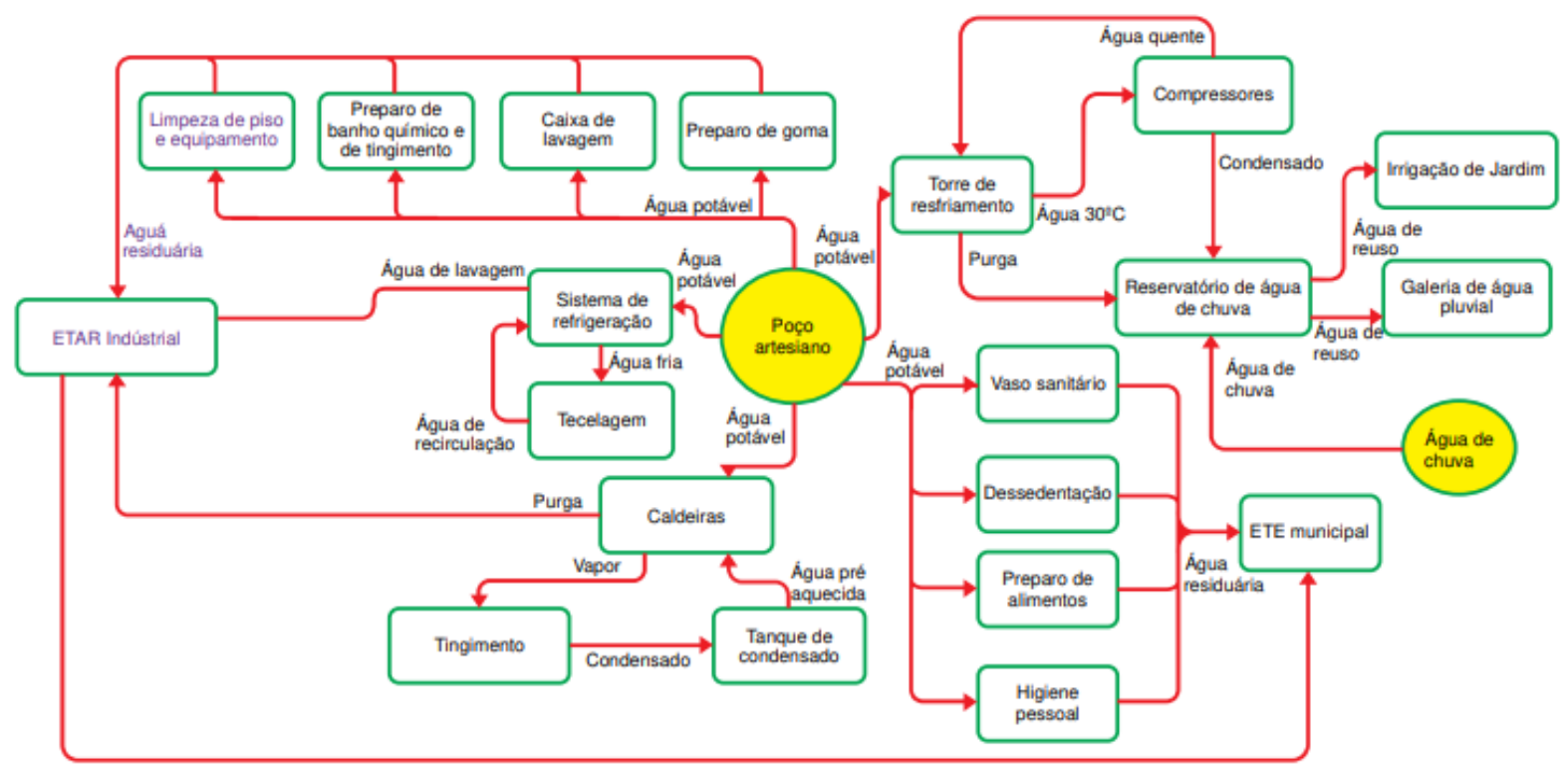

Fonte: Elaborado pelos autores, 2019.

Figura 07 - Identificação da água de reúso na empresa do estudo.

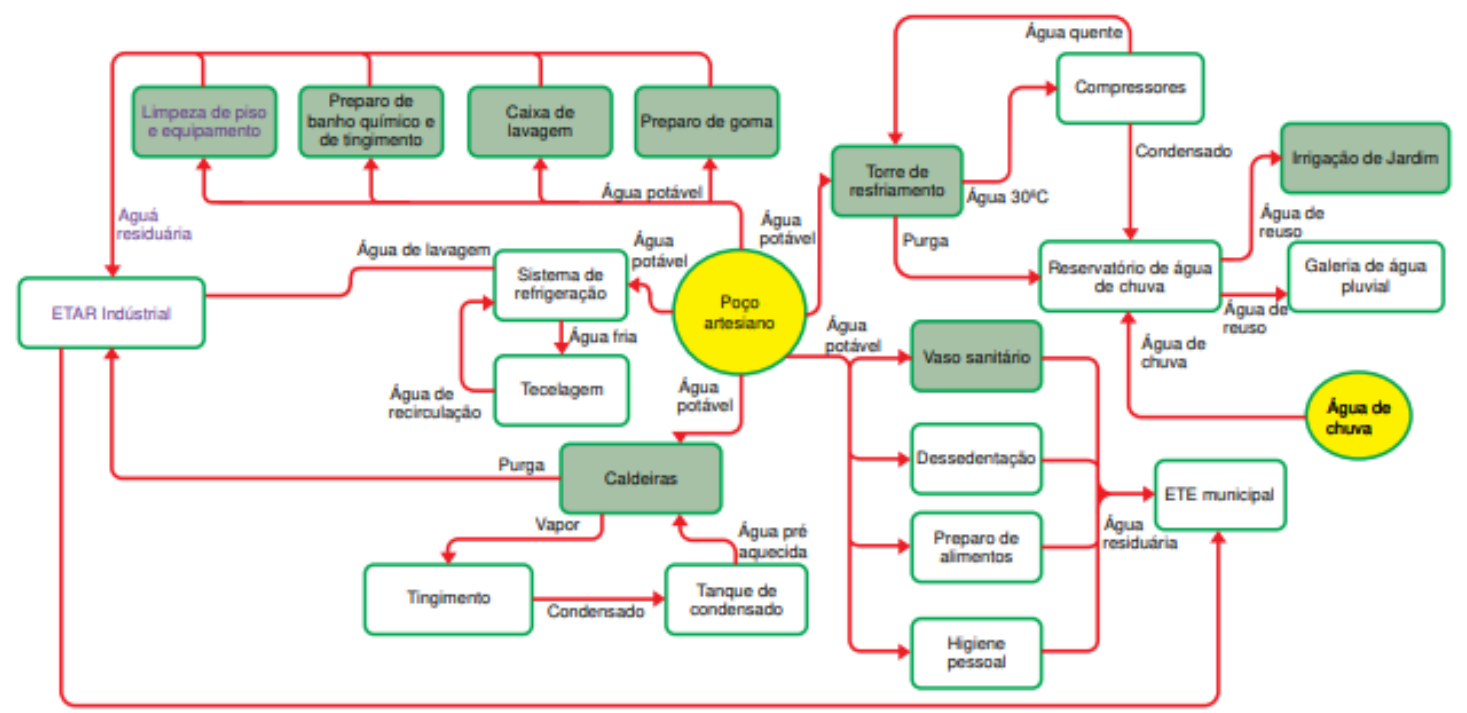

Reúso

Fonte de Água

Fonte: Elaborado pelos autores, 2019. 
A empresa está utilizando as águas de reúso e o consumo diário estimado da planta industrial está conforme indicado na Tabela 02. Após a identificação dos principais pontos de reúso foi determinada a qualidade mínima requerida da água para cada um desses pontos. O maior consumo de água acontece nas caixas de lavagem no processo de tingimento do denim, em que os fios ou cordas são imersos no banho de tingimento e após sobem pelos foulards para oxidação prensados para remover o excesso de banho. Nessa etapa são geradas as águas de transbordo que posteriormente serão tratadas na estação físico química de tratamento. As águas de reúso provenientes do tratamento físico químico são utilizadas na limpeza do piso e equipamento, no preparo de banho químico de tingimento, nas caixas de lavagem e no preparo da goma. Também são utilizadas nas caldeiras, torre de resfriamento e na irrigação do jardim. No vaso sanitário também foi adotado o sistema de reutilizar as águas tratadas provenientes do transbordo. A reutilização da água tratada gerou uma economia de aproximadamente 5000 litros de água por hora.

Tabela 02 - Estimativa do consumo e descarte de água na planta industrial.

\begin{tabular}{lc|c}
\hline & Consumo diário (litros) & Descarte diário (litros) \\
\hline Preparo de banho químico e tingimento & 16.553 & NC \\
Caixa de lavagem & 254.400 & 254.400 \\
Preparo de goma & 44.350 & $\mathrm{NC}$ \\
Lavagem de piso e equipamento & 72.000 & 72.000 \\
Torre de resfriamento & 19.000 & 19.000 \\
Caldeiras & 9.000 & 9.000 \\
Vaso Sanitário & 8.100 & $\mathrm{NC}$ \\
Irrigação de jardim & 3.750 & $\mathrm{NC}$ \\
Condensado dos compressores & NU & 2.400 \\
\hline NU: Não Utliza & & \\
NC: Não contabilizado & &
\end{tabular}

Fonte: Elaborado pelos autores, 2019.

Dessa forma, a $\mathrm{P}+\mathrm{L}$ contribui para que se tenham melhores condições de operação na empresa estudada. Além disso, a partir dos dados coletados verificou-se a importância de uma boa gestão ambiental e da $\mathrm{P}+\mathrm{L}$ na melhora da eficiência e do desempenho ambiental nos processos produtivos, além da mimimização dos impactos ambientals.

A água proveniente do tingimento é encaminhada para a rede pública de saneamento da cidade. Para que os flocos sejam formados é adicionado ao tratamento hidrossulfito $\mathrm{H}_{2} \mathrm{~S}$ que gera um odor desagradávele e libera um gás que cotem soda e cloro, desta forma a empresa instalou um lavador de gás da Eco Tech System, responsável por reduzir o hidrossulfito de sódio que contem enxofre e liberar menos gás no ambiente.

Quando se faz o tingimento do jeans preto as 5 caixas de lavagens fazem um trabalho contra corrente e otimiza o uso da água mantendo duas caixas com água limpa. A caldeira responsável pelo aquecimento dos banhos de tingimento é abastecida com gás natural e trabalha com águas de reúso. A descarga de fundo é utilizada nas lavagens para fixação do corante e remoção das gomas.

O consumo de água da empresa estudada é de $16 \mathrm{~m}^{3}$ por hora com 5 máquinas de tingimento, e antigamente eram utilizadas 3 máquinas e o consumo era de $25 \mathrm{~m}^{3}$ por hora. Em 1997, foi sancionada a 
lei das águas núemero 9.443 que estabeleceu a PNRH (Política Nacional de Recursos Hídricos) e criou o sistema SINGREH (Sistema Nacional de Gerenciamento de Recurso Hídricos). Um dos principais objetivos dessa lei é assegurar a disponibilidade de água, em padrões de qualidade adequados, bem como promover uma utilização racional e integrada dos recursos hídricos (GOVERNO DO BRASIL, 2010).

O reúso da água da chuva é uma melhoria da eficiência do processo na empresa através da P+L. São utilizados quatro litros e meio de água para cada metro de tecido produzido. Segundo a empresa pode-se obter o indicador ambiental pela foto do hidrômetro, porém eles não têm nenhum histórico desse registro.

Os efluentes líquidos produzidos pela atividade têxtil se caracterizam por apresentar elevada carga orgânica, alta concentração de sais e forte coloração. Estima-se que 15 a $50 \%$ da carga de corantes são perdidas nas etapas de tingimento e lavagem, o que torna clara a necessidade de sistemas de tratamento de efluentes têxteis. Outra importante constatação, é que uma parcela desses corantes resiste a processos biológicos convencionais, mesmo utilizando-se rotinas anaeróbio-aeróbias sequenciais.

Em função das deficiências apresentadas pelos sistemas convencionais de tratamento, eventualmente representados por processos biológicos e de coagulação química, novas alternativas de tratamento têm sido regularmente propostas. Dentro do contexto do reúso dos efluentes têxteis é possível destacar a associação de processos biológicos com processos de ultra e nanofiltração, a utilização de processos de oxidação eletroquímica e, menos frequentemente, o uso de rotinas envolvendo processos físico-químicos, biológicos e de adsorção em carvão ativado.

O volume diário consumido de água é $16 \mathrm{~m}^{3}$ de água por hora e o consumo geral da unidade é de $21 \mathrm{~m}^{3}$ por hora. $\mathrm{O}$ montante gerado de águas residuais no tingimento diariamente é de $16 \mathrm{~m}^{3}$ por hora e na empresa é de aproximadamente $18 \mathrm{~m}^{3}$ por hora.

O tratamento utilizado para tratar as águas de transbordo é fisico químico e consiste em tratar a água que está azul e torná-la apta ao reúso nas descargas, lavagens de patios, refeitório. O princípio desse tratamento é formar os flocos que serão prensados e encaminhados a companhia de aterro do município. As águas de tingimento após várias reutilizações são encaminhadas à rede de saneamento da cidade.

Os corantes utilizados pela empresa são o índigo e alguns sulforosos para o tingimento do jeans preto, por exemplo. As maiores dificuldades encontradas no tingimento do denim são as limitações do próprio processo, pois trata-se de uma prática antiga sem grandes avanços tecnológicos, tanto na linha de materiais como equipamentos. A empresa tentou utilizar o corante eco hidrossulfito, mas as características informadas pelo fornecedor não atendiam as especificações técnicas, além disso, a água de reúso tem muita condutividade elétrica, na ordem de $1500 \mathrm{~ms} / \mathrm{cm}$. A condutividade elétrica de uma solução de nutrientes e água pode ser expressa como Siemens por $\mathrm{cm}(\mathrm{S} / \mathrm{cm})$, millisimens por $\mathrm{cm}(\mathrm{mS} /$ $\mathrm{cm})$ ou Microsimens por $\mathrm{cm}(\mu \mathrm{S} / \mathrm{cm})$.

A $\mathrm{P}+\mathrm{L}$ evita a geração de resíduos, evita tratamentos e processos que demandem alto custo em energia consumida e dissipada. Essa ferramenta evita o consumo elevado e desperdício de água gera menos água residual e é uma ferramenta que dá apoio a gestão ambiental que administra os recusros naturais na fonte de modo a otimizá-los. A falta de água no mundo é algo real e a cobrança por esse recurso tão escasso será inevitável.

A empresa é engajada nas questões ambientais, porém a consciência só será plena o dia em que a água utilizada for paga. No momento é gratuita e nenhum investimento será recuperado em algo que não há ônus. Se a água for paga na proporção que é consumida, viabilizará o tratamento biológico por membranas e se tornará um investimento viável com rápido retorno.

A água que não é tratada evapora, tanto no processo de tingimento, nas caldeiras e no tratamento físico qúimico e o descarte é quase zero. Na Índia, por exemplo, ocorre havia muitos anos esse cenário nas in- 
dústrias de denim. A situação ambiental no mundo tem uma solução: através do mercado mensurado pelo cliente que exige qualidade, certificações ambientais, fornecedores socialmente e ambientalmente corretos, e através de uma legislação com penalidade rigorasa e auditorias que garantam o cumprimento delas.

Na verdade, a empresa já tínha uma redução do consumo de água no processo produtivo, entretanto segundo o gestor ambiental, a $\mathrm{P}+\mathrm{L}$ auxiliou no aprimoramento dessa prática. A implementacão da $\mathrm{P}+\mathrm{L}$ foi um rearranjo do processo produtivo do denim.

O teor de enxofre presente nos corantes que a empresa trabalha não requer um tratamento específico, apenas um filtro para reduzir o cheiro e a emissão de gás. A indústria é frequentemente auditada pelo IBAMA e pela CETESB, que são os órgãos de licenciamento ambiental. A empresa é modelo de relatórios e processos de implementação da $\mathrm{P}+\mathrm{L}$. Como a alta gestão e diretoria sempre tiveram a consciência ambiental, sempre propagaram esse lema aos colaboradores da companhia. A $\mathrm{P}+\mathrm{L}$ deveria ser uma condição obrigatória para qualquer funcionamento de uma instituição, como uma necessidade fisiológica para o bom funcionamento e prosperidade de um negócio.

Em janeiro de 2018 a companhia instalou uma ETE (Estacão de Tratamento de Efluentes). Com esse investimento aumentaram a vazão e eficiência do processo produtivo, um investimento de R \$ 1,5 milhões.

As caldeiras também passaram a ser a gás, reduzindo o consumo de energia elétrica. Uma ação importante para aempresa que impactou na redução do custo e impacto ambiental. A empresa também instalou um filtro de ar, pois o uso de hidrossulfito que reduz a cor da água tratata, azul escuro para uma água quase transparente, gerava um odor desagradável nas redondezas e a reivindicação da comunidade no entorno era constante.

O consumo de energia na empresa, a média de kw é contabilizado na totalidade, não há mensuração e controle por setor como demonstra a Tabela 03. Algumas medidas de substituição de caldeiras para o sistema a gás infinitamente mais econônima do que a elétrica e climatizadores naturais são utilizados na companhia.

Tabela 03- Consumo de Energia Mensal da Empresa - 2018.

\begin{tabular}{|c|c|c|c|c|c|c|}
\hline \multirow[b]{2}{*}{ CONSUMO } & JAN & FEV & MAR & ABR & MAIO & JUN \\
\hline & & & & & & \\
\hline \multirow{3}{*}{$\begin{array}{c}\text { ENERGIA } \\
\text { KWh }\end{array}$} & 449.914 & 1.650 .330 & 1.866 .583 & 1.847 .740 & 1.677 .096 & 1.827 .604 \\
\hline & & & & & & \\
\hline & JUL & AGO & SET & OUT & NOV & $\begin{array}{c}\text { TOTAL } \\
\text { ANO }\end{array}$ \\
\hline \multicolumn{7}{|l|}{ CONSUMO } \\
\hline $\begin{array}{c}\text { ENERGIA } \\
\text { KWh }\end{array}$ & 1.899 .393 & 1.924 .929 & 1.845 .405 & 1.937 .914 & 769.037 & 17.695 .945 \\
\hline
\end{tabular}

Fonte: Elaborado pelos autores, 2019.

A cor do efluente resultante dos processos de tingimento tem sido um dos cruciais impasses ambientais enfrentados pela indústria têxtil. Além da aparência estética a coloração presente no efluente têxtil prejudica a fotossíntese e causa problemas para a flora e a fauna aquática. Alguns padrões e limites aceitáveis foram 
estabelecidos e novas tecnologias foram buscadas para a remoção da cor causada por corantes.

A empresa em estudo tem uma representatividade no setor têxtil, pois está no ranking da quinta maior produtora de denim do país com 70 milhões de $\mathrm{m}^{2}$ por ano, matéria prima do jeans, um artigo mundialmente consumido. Representa um bom índice de empregabilidade e geração de impostos para a economia pois fatura $\mathrm{R} \$ 328$ milhões e tem um lucro líquido de $\mathrm{R} \$ 59.500$ milhões.

A elevada produção denim deve-se ao fato de ser um artigo mundialmente utlizado por todas as gerações e estilos de vida, que compõe a maior parte das ocasiões de vestuário. O processo produtivo do denim é muito complexo e utiliza uma elevada quantidade de água no processo de tingimento com o corante o indigo, gerando um exorbitante custo ambiental, já que além do elevado consumo requer também um tratamento adequado do efluente, cuja característica é elevada carga química, tonalidade azul escura e altos indices de DBO e DQO, características das águas residuais desse processo.

Para tentar solucionar esse agravante de imódico consumo de água a empresa utiliza a ferramenta de gestão $\mathrm{P}+\mathrm{L}$ que tem como premissa a utlização do recurso hídrico de forma sustentável mesmo nos processos de tingimento em que a água é uma matéria prima essencial.

A companhia é fiscalizada frequentemente pela CETESB e IBAMA e também por auditorias ambientais profissionais para que mantenha as outorgas de utilização e exploração dos poços artesianos. Esses procedimentos são propostos em legislação ambiental vigente nos manuais das câmaras ambientais da CETESB e nas licenças ambientais expedidas pelos orgãos competentes. Porém, sempre são sugeridos como boas práticas ambientais.

A P $+\mathrm{L}$ tem finalidades claras nessa indústria, na verdade um paradoxo, ela tanto reduz os custos ambientais como os prejuízos ambientais, pois as ações são aplicadas no início dos processos minimizando desperdícios e consumo de energia. A questão está nos processos de tratamento que não tem a devida importância já que a água não tem custo para empresa.

As questões culturais de exploração de recursos naturais fogem à realidade no que tange ao uso e ao desperdício. Não se valoriza ou não se tem práticas preventivas do que momentaneamente não é escasso e caro. Uma medida eficiente seria sobretaxar o recurso hídrico, pois somente dessa forma seriam exigidos em paralelos, tratamentos de efluentes mais modernos e eficazes, reduzindo também os custos da empresa de saneamento local.

$\mathrm{Na}$ era do estresse hídrico e aquecimento global é inconcebível que se liberem outorgas de poços artesianos sem restrições de uso. O consumo médio de uma família gira em torno de $20 \mathrm{~m}^{3}$ mês segundo, DAAE-Araraquara (2018), enquanto que nessa companhia o consumo diário é de $16 \mathrm{~m}^{3}$ de água por hora.

\section{CONSIDERAÇões FINAIS}

A indústria têxtil tem um elevado potencial poluidor não apenas pelo elevado consumo de recursos hídricos, mas também pelos altos volumes de efluentes gerados, ou seja, para cada quilo de material têxtil produzido são utilizados de 100 a 300 litros de água. A ferramenta de gestão $\mathrm{P}+\mathrm{L}$ abrange vários níveis da empresa e trata da melhoria da eficiência dos processos. As ações preventivas nos setores de fiação, tecelagem e tingimento minimizam a geração de resíduos, efluentes e da carga poluidora.

O consumo elevado de recursos hídricos da indústria têxtil gera uma grande quantidade de águas residuais que são caracterizadas pela elevada carga química. Os efluentes oriundos dos processos produtivos têxteis não devem ser eliminados no ecossitema sem que passem por tratamentos específicos antes de serem lançados nos corpos hídricos.

O processo produtivo do denim, assim como o corante indigo, de fato têm uma importante relevância para a economia mundial, visto que produzem um artigo de uso comum e globalmente aceito pelos indi- 
víduos, o jeans. Deve-se utilizar o recurso hídrico, muito solicitado nesse processo, de forma consciente, com reaproveitamento de banhos de tingimento, reúso e tratamento das águas residuais do processo. Assim como a utlização de águas de chuva apra lavagem de pisos, caldeiras e pisos.

As estratégias de $\mathrm{P}+\mathrm{L}$ utilizadas em indústrias têxteis na esfera mundial e no cenário nacional, mostraram que existem procedimentos utilizados nesse setor que diminuem o consumo de água, energia através da subsituição das caldeiras tradicionais elétricas por caldeiras movidas à gas, minimização da geração de resíduos e principlamente efluentes têxteis. A indústria têxtil pesquisada utiliza essa ferramenta de gestão $\mathrm{P}+\mathrm{L}$ e através dela minimiza o consume de água em seus processos produtivos, principalmente no tingimento do denim.

A água é um recurso barato e utlizado em abundância no Brasil, principlamente pelas indústrias têxteis que possuem tingimento em seus processos produtivos. A exploração e perfuração de poços artesianos promovem o uso de recursos hídricos em quantidades elevadas e águas com nível de potabilidade. Não obstante a esse fato, essas águas utilizadas pela indústria são posteriormente descartadas em corpos hídricos ou na rede de saneamento da região.

Para que isso ocorra dentro da legalidade ambiental são efetuados tratamentos caros e elaborados para que se diminua a carga química e poluente desse efluente. Uma questão bastante delicicada e comtraditória.

$\mathrm{Na}$ verdade, esse recurso hídrico deveria ser sobretaxado e também mantido as exigências legais ambientais propostas pela CETESB e pelo IBAMA de impactos e prejuízos ao meio ambiente. A ferramenta de gestão $\mathrm{P}+\mathrm{L}$ deveria ser uma premissa em todas as indústrias, principalmente a têxtil, para que o uso da água seja sempre otimizado e reduzido.

De acordo com dados levantados na empresa foi possível comprovar que de fato a companhia tem uma considerável importância para o desenvolvimento nacional econômico, devido as suas receitas produtivas e da amplitude comercial gerada pelo processo produtivo do denim, uma matéria prima mundial utilizada na fabricação do jeans, um artigo muito utizado pela população em diferentes estilos de vida. Outra importante constatação foi que as estratégias de $\mathrm{P}+\mathrm{L}$ utilizadas nos processos de gestão podem contribuir e muito na redução do consumo de água e energia através do reúso das águas de transbordo, resfriamento das caldeiras, lavagem de pisos e equipamentos. Não menos importante é a melhora da eficiência produtiva dos processos de tingimento e uso de matéria prima de forma consciente do ponto de vista econômico e ambiental.

O estresse hídrico é uma realidade mundial, hoje sentida em menores proporções no Brasil. Dessa forma, é questão de tempo a água se tornar um recurso sobretaxado, o que causaria um enorme prejuízo aos pequenos produtores têxteis que não estiverem prepararados e captalizados para esse cenário. Uma alternativa viável e ideal para as empresas de pequeno e médio porte é a utilização da ferramente de gestão $\mathrm{P}+\mathrm{L}$ em seus processos produtivos, principalmente as que trabalham com a etapa de tingimento, pois essa ferramenta atua preventivamente no consumo exacerbado de água, reduzindo custos e processos operacionais não efetivos e sem dúvida contribui para um cenário de menor estresse hídrico.

\section{REFERÊNCIAS}

ASSOCIAÇÃO BRASILEIRA DA INDÚSTRIA TÊXTIL E DE CONFECÇÃO ABIT -. Disponível em: $<$ http://www.abit.org.br>. Acesso em: 18.maio 2017.

ADVANTAGE AUSTRIA. Disponível em: <http://www.advantageaustria.org/international/zentral/ business-guide-oesterreich/importieren-aus-oesterreich/fashion/Ueberblick.pt.html >. Acesso em: abril. 
O uso sustentável da água: a produção mais limpa...

2018.

ALKAYA, E.; DEMIRER,G. N. Sustainable textile production: a case study from a woven fabric manufacturing mill in Turkey. Journal of Cleaner Production. [s.1.], v. 65 p. 595-603, july.2014.

ARAÚJO, M. C. C. Mapeamento da qualidade ambiental nas organizações privadas de Santa Catarina: ISO 14000 e produção mais limpa. 2004. Dissertação de Mestrado em Engenharia de Produção. Universidade Federal de Santa Catarina, Florianópolis. 2004.

BAI, Y.; YIN, J.; YUAN,Y.; GUO,Y.; SONG, D. An innovative system for promoting cleaner production: mandatory cleaner production audits in China. Journal of Cleaner Production. [s.l.], v.108 p. 883 - 890, December. 2015.

BDO BRAZIL. Auditoria Contábil. Disponível em: https://www.bdo.com.br/pt-br/servicos/auditoria/ auditoria-das-demonstracoes-contabeis. Acesso em: novembro. 2017.

CAPAR, G.; YILMAZ, L.; YETIS,U.; HAZARD. MAT. Membrane based strategies for the pre-treatment of acid dye bath wastewaters. Journal of Hazardous Materials, v.135., p. 423-430, 2006.

COMPANHIA AMBIENTAL DO ESTADO DE SÃO PAULO -CETESB. Disponível em: <http://cetesb. sp.gov.br/consumosustentavel/wpcontent/uploads/sites/20/2015/01/caso44.pdf >. Acesso em: março. 2020.

CONFEDERAÇÃO NACIONAL DA INDÚSTRIA- CNI, Encontro da indústria para a sustentabilidade. Brasília, 2012.

CONSELHO NACIONAL DE MEIO AMBIENTE-CONAMA. Resolução No 430 de 13 de maio de 2011, p.89.

CONCEITO AMBIENTAL - CONSULTORIA E ASSESSORIA . Disponível em: http://www.conceitoambiental.com.br/documentacao-ambiental/outorga-de-poco-artesiano. Acesso em: 06.nov.2018.

DASGUPTA, Jhilly et al.. Remediation of textile effluents by membrane based treatment techniques: A state of the art review. Journal Of Environmental Management, [s.1.], v. 147, p.55-72, jan. 2015.

FERSI, C.; GZARA, L.; DHAHBI, M. Treatment of textile effluents by membrane technologies. Desalination, [s.1.], v. 185, n. 1-3, p.399-409, nov. 2005.

FRESNER, J.; JANTSCHGI, J.; BIRKEL, S.; Barnthaler, J.; KRENN, C. The theory of inventive problem solving (TRIZ) as option generation tool within cleaner production projects. Journal of Cleaner Production. [s.l.], V. 18 p. 128 - 136, September. 2009.

GOTEXSHOW. FEIRA INTERNACIONAL DE PRODUTOS TÊXTEIS. Disponível em: < http:// gotexshow.com.br/mercado/>. Acesso em 29. Março. 2018.

MIGUEL, P. A. C. Estudo de caso na engenharia de produção: estruturação e recomendações para a sua 
condução. Produção, São Paulo. v.17, n.1, p.216-229, jan./abr. 2007.

MINISTRY OF INDUSTRY AND TRADE - MOIT. Turkish Industrial Strategy Document: towards EU Membership. Ankara. Disponível em: http://www.sanayi.gov.tr/ Files/Documents/TurkiyeSanayiStratejisiIngilizce.pdf. Acesso em: agosto. 2017.

NIINIMAKI, H. Emerging design strategies in sustainable production and consuption of textiles and clothing. Journal of Cleaner Production. Disponível em: <http:www.elsevier.com/locate/jclepro $>$. Acesso em: 14. nov.2017.

OZTURK, E.; KARABOYAC, M.; YETIS, U.; YIGIT , N. O.; KITIS, M. Evaluation of Integrated Pollution Prevention Control in a textile fiber production and dyeing mill. Journal of Cleaner Production. [s.l.], v. 88 p. 116 - 124, may. 2014.

PIMENTA, H. C. D; GOUVINHAS, R. P. Implementação da Produção mais Limpa em uma indústria têxtil: vantagen econômicas e ambientais. International workshop Advances in cleaner Production. “CLEANER PRODUCTION INITIATIVES AND São Paulo - Brazil - May, 2011.

Lei das águas assegura a disponibilidade do recurso no País. Disponível em: $<$ http:// www.brasil.gov.br/meio-ambiente/2010/10/lei-das-aguas-assegura-a-disponibilidade-do-recurso-nopais> Acesso em: 30 jun 2019.

SEIFFERT, M. E. B. Gestão ambiental: instrumentos, esferas de ação e educação ambiental. São Paulo: Atlas, 2009.

SELEGHIM, A. P. D; SILVA, A. J. Estudo Para Implantação de produção mais limpa no contexto das pequenas e médias empresas do segmento têxtil. ENGEMA - Encontro Internacional sobre Gestão Empresarial e Meio Ambiente. Disponível em: http://engemausp.submissao.com.br/18/anais/arquivos/383. pdf . Acesso em: 15. Maio. 2017.

SINDICATO DAS INDÚSTRIAS TÊXTEIS DE MALHAS NO ESTADO DE MINAS - SINDIMALHAS . História da indústria Têxtil no Brasil. Disponível em: <http://www.sindimalhas.com.br/estudos_ conteudo,14,6.html>. Acesso em: 17. maio. 2017.

SOTTORIVA, P. R. S. Degradação de corantes reativos utilizando-se processos oxidativos avançados Curitiba, 2002. 114 f. Dissertação (Mestrado em Química) - Setor de Ciências Exatas, Universidade Federal do Paraná, Curitiba, 2002.

REVISTA TÊXTIL. Turquia, onde se reúnem os tecidos da moda. Disponível em: <http://www.textilia. net/materias/ler/textil/negocios/turquia_onde_se_reunem_os_tecidos_da_moda $>$. Acesso em 29. março. 2018.

TMOSIT - Turkish Ministry of Science Industry and Technology. Textile, Garment, Leather and Leather Products Sectors Report and Analysis Series. Disponível em: < http://www.sanayi.gov.tr/DocumentList. aspx? catID=1435\&lng=tr $>$. Acesso em: maio. 2017. 
VERMA, A. K.; DASH, R.; BHUNIA, P. A review on chemical coagulation/flocculation technologies for removal of colour from textile wastewaters. Journal Of Environmental Management, [s.l.], v. 93, n. 1, p.154 -168, jan. 2012.

YIN, R. K. Estudo de caso: planejamento e métodos. 2. ed. Porto Alegre: Bookman, 2001.

ZAGONEL, L. M.; SCHULTZ, G. Produção mais limpa na indústria têxtil: alternativas para minimização da utilização de água no processo de tingimento e acabamento. Revista Destaques Acadêmicos, ano1, n.1, 2009 CGO. Disponível em: < http://www.univates.br/revistas/index.php/destaques/article/view/12>. Acesso em: 17. outubro.2017. 